\title{
The Impact Of Ethnic Background On Perceptions Of Homeownership
}

\author{
Geoffrey T. Stewart, University of Louisiana \\ Lawrence Williams, University of Louisiana \\ John Tanner, University of Louisiana
}

\begin{abstract}
This study sought to address this issue by measuring factors like responsible financial performance, financial knowledge, product expertise, and purchase intentions to determine if ethnic background significantly impacted one's progression towards homeownership. This study sampled college students since the majority of these students currently do not own a home and have lower personal incomes.
\end{abstract}

\section{INTRODUCTION}

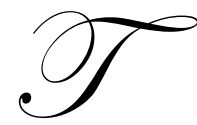

he United States housing market is currently facing a crisis over the fate of subprime mortgages and potential foreclosures. These types of mortgages, while beneficial to some clients, are particularly regressive on households that either did not adequately prepare for rising interest rates or that did not fully understand the requirements of interest only and adjustable rate mortgages. In particular, low-income and minority clients are particularly vulnerable to predatory lenders because they may not have the requisite knowledge of the home mortgage business and thus are easy to persuade in areas like variable interest rates (Murray 2002).

Additionally, lending programs targeting minority customers have been instituted nationwide by state governments, local community development organizations, the NAACP, Fannie Mae, and Freddie Mac to name a few. Through the efforts of these organizations, money is invested into special financing products which ultimately target minority customers who are seeking to purchase their first home. While these programs assist the lending agencies in developing value propositions for the market, the programs do not necessarily educate potential households in the area of homeownership (Dixon 1999).

The knowledge of financial products and responsibility involved in maintaining the financial health of the household are two particular areas where lending and community institutions could provide valuable financial education. Currently, marketing practice in financial markets appears to revolve around identifying customers that are interested in their financial well-being and motivated to seek out assistance from financial institutions. In lowincome and minority markets, institutions are likely to confront citizens that will need assistance in understanding the role of financial institutions, the services these institutions can provide, and the type of financial-discipline needed to improve the financial viability of the household.

There is a tremendous opportunity for the marketing community to determine if ethnic background significantly impacts one's progression towards homeownership. This study explores this issue by investigating the role of ethnicity in the areas of responsible financial performance, financial knowledge, product expertise, and intention to purchase a home. In assessing each of these variables, the research team will determine if there is a statistically significant difference between the responses of ethnic groups.

\section{LITERATURE REVIEW}

The impact of ethnicity in financial markets is widely discussed in the literature (Armstrong 2004; Bostic and Martin 2005; Brimmer 1986; Gabriel and Painter 2003). In particular, there are several issues which are sited as 
being barriers to homeownership and affordability. These variables include (1) limited homeownership/buying education within minority groups, (2) development regulations which increase the cost of housing, (3) predatory lending practices, like subprime loans, which raise the risk of foreclosure and increase the mortgage cost, (4) regulations on multifamily developments which in turn reduce the availability of moderately priced homes, and (5) violations of the Fair Housing Act that eliminate the access to housing in many neighborhoods for minority families (Leopold 2006). Of these barriers, this study will explore the issue of homeownership/buying education within minority groups by measuring (1) responsible financial behavior, (2) financial knowledge, and (3) product expertise. Lastly, future purchase intention of a home will be measured to assess the differences amongst ethnic groups with regard to homeownership.

\section{Responsible Financial Behavior}

The efforts of government agencies, consumer groups, and financial institutions to develop outreach programs for the dissemination and education of consumers are widely recognized valuable strategies in stimulating a more financially responsible consumer base (Perry and Morris 2005). As described by Perry and Morris (2005), responsible financial behavior is "the respondent's self-assessed propensity to budget, save money, and control spending" (p. 300). As an indicator of behavior, responsible financial behavior seeks to provide insight into the financial behavior of respondents. Responsible financial behavior should serve as a prerequisite to homeownership in that consumers must demonstrate a certain level of responsibility before they can attain a desired credit level or money for an initial loan down payment.

\section{Financial Knowledge}

As explained by Perry and Morris, "financial service providers including credit card companies and other lending institutions as well as social marketers claim that the high incidence of bankruptcies, credit problems, poor savings rates, and impulse buying are largely a result of a lack of financial knowledge on the part of consumers" ( $p$. 299). Further, the lack of financial understanding stems from the inherent complexity of financial information and the inaccessibility of this information to some consumers (Chang and Hanna 1992). Herein lies the challenge for lending organizations when attempting to market these financial product to consumers.

From a marketing standpoint, the challenge is not to convince someone that homeownership is desirable. The challenge is to assist a consumer in understanding the benefits of homeownership and in helping them to develop the financial responsibility to create a position from which to act. To help in this endeavor, lenders and consumer can call upon formal education training, seminars, parents, friends, and personal experiences as sources of information. The measurement of financial knowledge in this study seeks to explain the participant's level of knowledge on (1) interest rates, finance charges, and credit terms, (2) credit ratings and credit files, (3) managing finances, (4) investing money, and (5) what is on their credit report.

\section{Product Expertise}

From the beginning of this study, it was assumed that consumers who do not own a home would have a low level of home buying expertise. As defined by Alba and Hutchinson (1987), product expertise is defined as the participant's "ability to perform product-related tasks successfully" (p. 411). This study did to measure the second dimension, familiarity, of Alba and Hutchinson's (1987) product class knowledge because it sought to capture consumer experiences related to a product category and the study's sample was designed to only include those who do not have experience with home ownership (Mishra, Umesh, and Stem 1993). In the case of homeownership, participants were asked to evaluate their (1) level of home ownership knowledge, (2) level of experience with home ownership, (3) extent to which they believe they are informed or uninformed in the area of home ownership and (5) extent to which they feel they are a novice or expert in the home ownership arena.

The product expertise construct is critical to the future success of institutional marketing because many financial institutions are calling upon consumers to become more self-reliant. For instance, lenders offer reduced interest rates if a consumer can navigate the lender's web-based application and payment processes. As banks 
reduce the range of full-service options, the consumer is called upon to engage in more self-service opportunities. Without the requisite product expertise, many consumers may face difficulty in doing business with an institution because they either do not possess the expertise to do it themselves or cannot afford the higher transaction fees that are beginning to accompany full-service options.

\section{Purchase Intention}

The final variable investigated in this study focused on the respondents' future home purchasing behavior. In looking at purchase intention, it is important to understand the current use situation of the sample. The sample included college-aged students from a multitude of ethnic and socioeconomic backgrounds. Because of the differences in the sample, purchase intention was examined under different timeframes. As a measure of purchase intention, the likelihood that a participant would buy a home was asked within the timeframes of immediately after graduation, the next time you move, and during your lifetime (Bone and Ellen 1992).

\section{METHODOLOGY AND RESULTS}

In order to assess college student's thoughts, perceptions, and attitudes toward home ownership, a questionnaire was administered to a convenience sample of 418 students at a regional university in South Louisiana. Many of these students had been either directly or indirectly affected by the devastation of Hurricanes Katrina and Rita in 2005, and therefore, their attitudes about home ownership would be very relevant to the attitudes of others in the area. In addition to some relevant demographic questions and other attitudinal questions, the survey instrument/questionnaire contained five self-assessment questions related to responsible financial performance (Perry and Morris 2005), six questions related to financial knowledge (Perry and Morris 2005), four Likert-type statements related to product expertise (Mishra et al. 1993), and five Likert-type questions related to purchase intentions (Bone and Ellen 1992).

Table 1 presents a demographic profile of the respondents. As seen in the table, almost 63 percent of the respondents were females, with more than 43 percent African-Americans and more than 50 percent Caucasians. More than 58 percent were college juniors or seniors, and more than 43 percent earned less than fifteen thousand dollars per year before taxes, which is expected for full-time college students. Additionally, more than three-fourths of the respondents said their parents owned their homes, and slightly less than one-fourth rented their homes.

Table 2 shows the percent of responses to the five self-assessment questions related to responsible financial performance. As the table shows, more than fifty percent of the respondents graded themselves highly (good or excellent) on controlling their spending. Slightly less than 70 percent gave themselves highly on paying their bills on time, while slightly more than 47 percent gave themselves good grades on planning for their financial future. When asked how they scored on providing for themselves and their families, again slightly less than 70 percent graded themselves highly. Lastly, when asked to assess themselves on how well they did when it comes to saving money, more than 43 percent gave themselves scores of either good or excellent.

Table 3 shows the percent responses to questions dealing with financial knowledge. More than 77 percent of the respondents had at least some knowledge or more about interest rates, finance charges, and credit terms, with more than 26 percent stating that they were very knowledgeable about these things. More than 70 percent had at least some knowledge or better about credit ratings and credit files, and 77 percent stated that they had some knowledge or better about managing finances. More than 62 percent stated that they had at least some knowledge or better about investing money, and slightly less than 62 percent stated that they had some knowledge or more about what appears on their credit reports. Lastly, only about 42 percent said they had at least some knowledge about mortgage options. 
Table 1

Demographic Profile of Respondents

\begin{tabular}{|c|c|}
\hline Demographic Characteristic & Percent of Respondents \\
\hline \multicolumn{2}{|l|}{ Gender: } \\
\hline Female & 63.9 \\
\hline Male & 36.1 \\
\hline \multicolumn{2}{|l|}{ Race/Cultural Background: } \\
\hline African-American & 43.1 \\
\hline Asian-American & 1.3 \\
\hline Caucasian & 50.5 \\
\hline Hispanic American & 0.3 \\
\hline Native American & 0.3 \\
\hline Other & 4.5 \\
\hline \multicolumn{2}{|l|}{ Current Education Level: } \\
\hline College Freshman & 9.3 \\
\hline College Sophomore & 19.2 \\
\hline College Junior & 21.1 \\
\hline College Senior & 37.0 \\
\hline Graduate Student & 6.1 \\
\hline Other & 7.3 \\
\hline \multicolumn{2}{|l|}{ Total Pre-Tax Income of Respondent (and Spouse): } \\
\hline Less than $\$ 15,000$ & 43.1 \\
\hline$\$ 15,000-\$ 24,999$ & 16.6 \\
\hline$\$ 25.000-\$ 34,999$ & 10.9 \\
\hline$\$ 35,000-\$ 44,999$ & 8.6 \\
\hline$\$ 45,000-\$ 54,999$ & 7.4 \\
\hline$\$ 55,000-\$ 65,999$ & 3.5 \\
\hline$\$ 66,000-\$ 74,999$ & 2.9 \\
\hline$\$ 75,000-\$ 100,000$ & 3.5 \\
\hline More than $\$ 100,000$ & 3.5 \\
\hline \multicolumn{2}{|l|}{ Before attending college, did your parents own their own home? } \\
\hline Yes & 75.6 \\
\hline No & 24.4 \\
\hline \multicolumn{2}{|l|}{ Before attending college, did your parents rent their home? } \\
\hline Yes & 24.7 \\
\hline No & 75.3 \\
\hline
\end{tabular}

Table 2

Responses to Questions Related to Self-Assessment of Responsible Financial Performance

\begin{tabular}{|c|c|c|c|c|c|c|c|}
\hline \multirow[b]{2}{*}{ How would you grade yourself on: } & \multicolumn{5}{|c|}{ Percent of Respondents } & \multirow[b]{2}{*}{ Mean* } & \multirow[b]{2}{*}{ Std. Dev.* } \\
\hline & Poor & Fair & Okay & Good & Excellent & & \\
\hline Controlling your spending & 9.3 & 11.7 & 27.8 & 38.5 & 12.7 & 3.33 & 1.13 \\
\hline Paying your bills on time & 3.3 & 4.8 & 22.5 & 45.7 & 23.7 & 4.04 & 1.13 \\
\hline Planning for your financial future & 9.1 & 12.2 & 31.3 & 31.3 & 16.1 & 3.33 & 1.16 \\
\hline Providing for yourself and your family & 3.3 & 4.8 & 22.5 & 45.7 & 23.7 & 3.82 & 0.96 \\
\hline Saving money & 15.5 & 15.8 & 25.4 & 29.7 & 13.6 & 3.10 & 1.27 \\
\hline
\end{tabular}

*1 = Poor; 2 = Fair; 3 = Okay; 4 = Good; 5 = Excellent 
Table 3

Responses to Questions Related to Financial Knowledge

\begin{tabular}{|c|c|c|c|c|c|c|c|}
\hline \multirow[b]{2}{*}{ How much do you know about: } & \multicolumn{5}{|c|}{ Percent of Respondents } & \multirow[b]{2}{*}{ Mean* } & \multirow[b]{2}{*}{$\begin{array}{l}\text { Std. } \\
\text { Dev.* }\end{array}$} \\
\hline & Nothing & $\begin{array}{l}\text { Very } \\
\text { Little }\end{array}$ & Some & $\begin{array}{l}\text { More than } \\
\text { a Small } \\
\text { Amount }\end{array}$ & $\begin{array}{l}\text { Very } \\
\text { Knowledgeable }\end{array}$ & & \\
\hline $\begin{array}{l}\text { Interest rates, finance charges, } \\
\text { and credit terms }\end{array}$ & 6.3 & 16.1 & 34.7 & 26.8 & 16.1 & 3.30 & 1.11 \\
\hline Credit ratings and credit files & 10.0 & 19.4 & 30.3 & 25.0 & 15.3 & 3.10 & 1.20 \\
\hline Managing finances & 6.0 & 15.0 & 27.9 & 32.4 & 18.7 & 3.43 & 1.13 \\
\hline Investing money & 10.0 & 27.9 & 31.6 & 18.1 & 12.4 & 2.95 & 1.17 \\
\hline What is on your credit report & 17.4 & 19.7 & 14.7 & 21.9 & 26.3 & 3.20 & 1.46 \\
\hline Home mortgage options & 28.2 & 30.0 & 18.9 & 14.5 & 8.4 & 2.45 & 12.7 \\
\hline
\end{tabular}

*1 = Nothing; 2 = Very Little; 3 = Some Knowledge; 4 = More than a Small Amount; 5 = Very Knowledgeable

Table 4 shows responses to questions related to product expertise. Specifically, respondents were asked to rate themselves on a continuum from 1 to 7 , as potential home owners, as to their expertise/knowledge about home ownership, their experience with respect to home ownership, degree to which they were informed or uninformed about home ownership, and degree to which they were novice or expert buyers of homes. The higher the rating, the greater the level of knowledge, experience, degree of infirmity, and expertise. As the table shows, these respondents had relatively low levels in all four areas. This might be somewhat expected, since most of the respondents were college students who are still living with their parents, and have not been exposed to home ownership situations themselves.

Table 4

Results of Responses to Questions Related to Product Expertise

\begin{tabular}{|c|c|c|}
\hline Product Expertise Questions & Mean & Std. Dev. \\
\hline 1. How would you rate your level of knowledge about home ownership? & 2.78 & 1.30 \\
\hline 2. How would you rate your level of experience about home ownership? & 2.01 & 1.32 \\
\hline 3. How would you rate the degree to which you are informed about home ownership? & 2.94 & 1.34 \\
\hline $\begin{array}{l}\text { 4. Where would you rate yourself as to whether you are a novice or an expert when it comes to } \\
\text { buying a home? }\end{array}$ & 1.92 & 1.18 \\
\hline
\end{tabular}

*1 = Very Little Knowledge; 7 = Extremely Knowledgeable

** 1 = Completely Inexperienced; 7 = Very Experienced

$* * * 1=$ Completely Uninformed; $7=$ Very Informed

$* * * * 1=$ Novice Buyer; $\quad 7=$ Expert Buyer

Table 5 shows responses to questions focusing on purchase intentions, as related to the purchase of a home. Respondents were asked to rate their intentions on a scale from 1 (no chance) to 11 (virtual certainty) on questions concerning the likelihood of home ownership. When asked the likelihood if they would purchase a home immediately after they graduated, the respondents were relatively evenly-divided, with more than 22 percent stating that there was no chance, and almost 14 percent stating that they were almost certain that they would buy a home. And, when asked if they would rent a home immediately after graduation, respondents were again somewhat evenlydivided, with 28 percent saying there was no chance of this and more than 10 percent stating that they were almost certain they would rent. 
Table 5

Responses to Questions Related to Home Ownership Purchase Intentions

\begin{tabular}{|l|c|c|}
\hline Purchase Intention Questions & Mean* & Std. Dev.* \\
\hline 1. What is the likelihood that you will purchase a home immediately after graduation? & 5.03 & 3.42 \\
\hline 2. What is the likelihood that you will rent a home immediately after graduation? & 4.99 & 3.53 \\
\hline 3. What is the likelihood that you will purchase a home during your lifetime? & 10.63 & 1.21 \\
\hline 4. What is the likelihood that you will rent a home/apartment for the rest of your life? & 2.00 & 1.78 \\
\hline 5. What is the likelihood that you will purchase a home the next time you move? & 5.60 & 3.74 \\
\hline
\end{tabular}

*1 = No Chance; 11 = Virtual Certainty

Respondents were much more certain that they would buy a home sometime during their lifetimes, with more than 86 percent stating that they were practically certain of it. Likewise, more than 61 percent said that there was no chance that they would rent an apartment or home for the rest of their lives. Lastly, when asked the likelihood that they would purchase a home the next time they moved, respondents were again middle-of-the-road in their responses, with more than 21 percent saying that there was no chance, and more than 20 percent stating that they were virtually certain of it.

Table 6 shows the result of significance tests between African-American and Caucasian respondents (these were by far the two largest ethnic groups) on all the above-mentioned questions. With respect to the questions focusing on responsible financial performance, significant differences were found on questions about controlling spending and paying bills on time, wherein Caucasian respondents graded themselves significantly higher than did the African-American respondents. With respect to self-assessments on planning for financial futures, providing for themselves and their families, and saving money, no significant differences were found between African-American and Caucasian respondents (both groups gave themselves average scores on these items).

Table 6

Comparisons of African-American and Caucasian Respondents on All Home Ownership Questions

\begin{tabular}{|c|c|c|c|c|c|c|}
\hline \multirow[b]{2}{*}{$\begin{array}{l}\text { RESPONSIBLE FINANCIAL PERFORMANCE } \\
\text { Questions: }\end{array}$} & \multicolumn{2}{|c|}{ African-Americans } & \multicolumn{2}{|c|}{ Caucasians } & \multirow[b]{2}{*}{$\mathbf{t}$} & \multirow[b]{2}{*}{ p-value* } \\
\hline & Means** & $\begin{array}{c}\text { Std. } \\
\text { Devs** }\end{array}$ & Means** & $\begin{array}{c}\text { Std. } \\
\text { Devs. } * *\end{array}$ & & \\
\hline \multicolumn{7}{|l|}{ How would you grade yourself on: } \\
\hline Controlling your spending & 3.16 & 1.14 & 3.49 & 1.03 & 2.60 & $.010^{*}$ \\
\hline Paying your bills on time & 3.81 & 1.29 & 4.29 & 0.89 & 3.72 & $.000^{*}$ \\
\hline Planning for your financial future & 3.24 & 1.22 & 3.42 & 1.07 & 1.30 & .196 \\
\hline Providing for yourself and your family & 3.89 & 0.97 & 3.82 & 0.86 & 0.62 & .537 \\
\hline Saving money & 2.94 & 1.22 & 3.22 & 1.23 & 1.91 & .057 \\
\hline$* * 1=$ Poor; 5 = Excellent & & & & & & \\
\hline
\end{tabular}

\begin{tabular}{|c|c|c|c|c|c|c|}
\hline \multirow[b]{2}{*}{ FINANCIAL KNOWLEDGE Questions: } & \multicolumn{2}{|c|}{ African-Americans } & \multicolumn{2}{|c|}{ Caucasians } & \multirow[b]{2}{*}{$\mathbf{t}$} & \multirow[b]{2}{*}{ p-value* } \\
\hline & Means** & $\begin{array}{c}\text { Std. } \\
\text { Devs** }\end{array}$ & Means** & $\begin{array}{c}\text { Std. } \\
\text { Devs.** }\end{array}$ & & \\
\hline \multicolumn{7}{|l|}{ How much do you know about the following: } \\
\hline Interest rates, finance charges, and credit terms & 3.37 & 1.13 & 3.32 & 1.07 & 0.42 & .676 \\
\hline Credit ratings and credit files & 3.37 & 1.20 & 3.05 & 1.18 & 2.30 & $.022 *$ \\
\hline Managing finances & 3.45 & 1.14 & 3.47 & 1.09 & 0.13 & .899 \\
\hline Investing money & 2.90 & 1.21 & 2.98 & 1.13 & 0.62 & .535 \\
\hline What is on your credit report & 3.56 & 1.47 & 2.91 & 1.38 & 3.91 & $.000 *$ \\
\hline Home mortgage options & 2.50 & 1.27 & 2.37 & 1.26 & 0.88 & .380 \\
\hline
\end{tabular}


Table 6(cont'd.)

Comparisons of African-American and Caucasian Respondents on All Home Ownership Questions

\begin{tabular}{|c|c|c|c|c|c|c|}
\hline \multirow[b]{2}{*}{ PRODUCT EXPERTISE Questions: } & \multicolumn{2}{|c|}{ African-Americans } & \multicolumn{2}{|c|}{ Caucasians } & \multirow[b]{2}{*}{$\mathbf{t}$} & \multirow[b]{2}{*}{ p-value* } \\
\hline & Means** & $\begin{array}{c}\text { Std. } \\
\text { Devs** }\end{array}$ & Means** & $\begin{array}{c}\text { Std. } \\
\text { Devs. } * *\end{array}$ & & \\
\hline $\begin{array}{l}\text { 1. How would you rate your level of knowledge about } \\
\text { home ownership? }\end{array}$ & 2.76 & 1.29 & 2.75 & 1.29 & 0.11 & .915 \\
\hline $\begin{array}{l}\text { 2. How would you rate your level of experience about } \\
\text { home ownership? }\end{array}$ & 1.89 & 1.20 & 2.01 & 1.35 & -0.78 & .434 \\
\hline $\begin{array}{l}\text { 3. How would you rate the degree to which you are } \\
\text { informed about home ownership? }\end{array}$ & 2.88 & 1.33 & 2.92 & 1.32 & -0.23 & .815 \\
\hline $\begin{array}{l}\text { 4. Where would you rate yourself as to whether you are } \\
\text { a novice or an expert when it comes to buying a home? }\end{array}$ & 1.81 & 1.09 & 1.91 & 1.21 & -0.77 & .444 \\
\hline
\end{tabular}

\begin{tabular}{|c|c|c|c|c|c|c|}
\hline \multirow[b]{2}{*}{ PURCHASE INTENTIONS Questions: } & \multicolumn{2}{|c|}{ African-Americans } & \multicolumn{2}{|c|}{ Caucasians } & \multirow[b]{2}{*}{$\mathbf{t}$} & \multirow[b]{2}{*}{ p-value* } \\
\hline & Means** & $\begin{array}{c}\text { Std. } \\
\text { Devs** }\end{array}$ & Means** & $\begin{array}{c}\text { Std. } \\
\text { Devs.** }\end{array}$ & & \\
\hline \multicolumn{7}{|l|}{ What is the likelihood that you: } \\
\hline Will purchase a home immediately after graduation? & 5.19 & 3.32 & 4.99 & 3.42 & 0.49 & .626 \\
\hline Will rent a home immediately after graduation? & 5.12 & 3.49 & 5.11 & 3.54 & 0.02 & .988 \\
\hline Will purchase a home during your lifetime? & 10.73 & 0.97 & 10.62 & 1.19 & 0.82 & .410 \\
\hline Will rent a home/apartment for the rest of your life? & 1.96 & 1.75 & 1.99 & 1.80 & -0.15 & .882 \\
\hline Will purchase a home the next time you move? & 5.49 & 3.59 & 5.72 & 3.85 & -0.51 & .612 \\
\hline
\end{tabular}

*Significant at $\alpha=.05$

On the questions about the financial knowledge of the respondents, African-Americans had a significantly higher level of knowledge about credit ratings and credit files, and about what was on their credit reports than did the Caucasian respondents. Both ethnic groups had about the same average level of knowledge about interest rates/finance charges/credit terms, managing finances, and investing money. Also, both groups had about the same low level of knowledge about home mortgage options.

With respect to the respondents' product expertise about home ownership, no significant differences were found between African-Americans and Caucasians on any of the questions. Both groups exhibited low levels of knowledge about home ownership, experience, and degree of infirmity about home ownership. Also, both groups were relative novices when it comes to home ownership.

The last portion of Table 6 asked questions about purchase intentions. No significant differences were found between African-American and Caucasian respondent on any of the questions. Both groups could be said to be relatively uncertain as to whether they would rent or purchase a home immediately after graduation, and whether they would buy a home the next time they moved. However, both groups were almost certain that they would purchase a home during their lifetimes, and both groups felt like the chances were very low that they would rent a home or an apartment for the rest of their lives.

\section{RESEARCH LIMITATIONS}

The utilization of a college student sample is a limitation of this study. First, college students are exposed to financial products either through saving their own money for tuition, through parents paying for expenses, and/or through financial aid products. This exposure inherently raises the level of understanding of financial related products because it forces students to utilize financial knowledge (even limited knowledge) when enrolling in school. Second, some students may have been enrolled in or completed finance related courses. These students would naturally have a higher understanding of financial products and may not be representative of the overall 
population. Lastly, the convenience sample was assimilated around the business college building at a university in South Louisiana. Given the location, the sample may have been predisposed to approach the survey from a business perspective and may have responded from a perspective that is "expected" of business students.

\section{IMPLICATIONS AND FUTURE RESEARCH}

\section{Influence Of Ethnicity}

Ethnicity was found to have a significant impact upon responses in only two areas of this study. First, with respect to the questions focusing on responsible financial performance, significant differences were found on questions about controlling spending and paying bills on time, wherein Caucasian respondents graded themselves significantly higher than did the African-American respondents. Second, African-Americans had a significantly higher level of knowledge about credit ratings and credit files, and about what was on their credit reports than did the Caucasian respondents. The responses in these areas are intriguing because the income level of respondents was similar across respondents (over $43 \%$ were less than $\$ 15 \mathrm{~K}$ ).

Future research is needed to understand the role of ethnicity by measuring the home ownership behavior of parents and to see if this impacts the home ownership intentions of their children. Additionally, research is needed to see if African-Americans are more vulnerable to predatory marketing practices. In the current sample, income was consistent across ethnic groups, but knowledge of credit ratings and files were higher in the African-American sample. This may be an indicator that the African-American in the sample have had more exposure (either their own experience or that of family, friends, etc.) to issues dealing with obtaining credit or managing a credit rating.

\section{Responsible Financial Behavior And Financial Knowledge}

The responses pertaining to responsible financial behavior and financial knowledge portray a sample that perceives its behavior to be largely responsible and that has some financial knowledge. Due to the perceptual nature of this research, these findings must be viewed with caution. While the sample may feel they have financial knowledge it does not necessarily mean that the knowledge is adequate to provide the customer with the requisite financial confidence to embark on purchasing a first home.

\section{Product Expertise}

The confidence needed to pursue home ownership was reflected in the area of product expertise. While consumers felt they understood credit ratings, savings, etc. and felt they were financially responsible, they also demonstrated a low level of expertise in the buying process related to real estate. This finding is expected since the sample was comprised of college students which do not own a home. The respondents do not have experience with the home buying process and thus should demonstrate a low level of expertise. Ethnicity did not produce a significant difference in responses on product expertise and this highlights an opportunity for financial service providers to engage customers in an education process that address the complexity of the purchase. Given the findings, the education process is need for all customers, regardless of ethnic background.

\section{The Marketing Implications Of Financial Knowledge And Product Expertise}

As with any service, lending institutions must be concerned about the value customers desire to receive from buying a home. As defined by Woodruff (1997), customer value is "a customer's perceived preference for and evaluation of those product attributes, attribute performances, and consequences arising from use that facilitate (or block) achieving the customer's goals and purposes in use situations" (p. 142). Based on this definition, the customer value hierarchy highlights the presence of three levels or dimensions of the customer value phenomena (Woodruff 1997). First, attributes represent characteristics of the value offering which are embedded in the product or service. In the case of home mortgages, attributes would be interest rate, mortgage amount, PMI, etc. Second, consequences are reflective of benefits or costs which customers experience as a result of consuming particular product or service attributes. Lenders articulate consequences to first-time home buyers when discussing issues like 
equity, owning your "own" home, creating a "place to call home," etc. Lastly, goals or purposes represent the end states which customers seek to accomplish through the use of particular product or service and through the creation of particular consequences. These goals may be reflected in a customers desire to provide security to the family by owning their own home or to create stability in their family by creating a consistent location where each day can begin and finish.

This customer value hierarchy is supported in this study. The respondents have a desire to own a home and understand the consequences which it may create for them and their families. However, the low level of product expertise reflects the inability of respondents to understand the product/service attributes. The home buying process is incredibly complex and requires the assistance of trained professionals. With low levels of expertise, this also requires the ability to trust the trained professionals. While this may sound elementary, trusting someone to assist in spending money (which may be limited) is a difficult task.

Future research is needed to explore the role of ethnicity in the development of relationships between consumers and financial representatives. This research is important because it may identify areas other than financial knowledge, responsible financial behavior, and product expertise that are influenced by ethnicity and that create barriers for minorities approaching home ownership decisions. For instance, if a customer is raised in a neighborhood where financial institutions do not have locations, do residents in these areas (1) use financial services, (2) exposed to the marketing of financial services and (3) trust financial institutions to do what is in their best interest. Additionally, research is needed to identify marketing practices which can better position financial institutions to build relationships with lower-income, first time homebuyers. While government programs are helpful, Hurricanes Katrina and Rita provided evidence that lower-income citizens were more apt to trust social networks and churches than local, state, and federal government. Given this evidence, financial services may need to leverage social networks and churches in the positioning of programs that mean well and seek to help customers purchase their first home.

\section{CONCLUSION}

This study sought to address this issue by measuring factors like responsible financial performance, financial knowledge, product expertise, and purchase intentions to determine if ethnic background significantly impacted one's progression towards homeownership. This study sampled college students since the majority of these students currently do not own a home and have lower personal incomes. Overall, ethnicity produced differences in two items that related to financial knowledge and responsible financial behavior. In the other areas, ethnicity did not demonstrate significant differences in responses. The lack of significant differences highlights the need for financial service providers recognize the inherent complexity of the buying process and to assist in the development of home ownership expertise, across all ethnic groups.

\section{REFERENCES}

1. $\quad$ Armstrong, Lisa (2004), A Home Is The Foundation For Wealth, Black Enterprise, 34 (6), 54.

2. Bone, Paula Fitzgerald and Pam Scholder Ellen (1992), The Generation and Consequences of Communication-Evoked Imagery, Journal of Consumer Research, 19 (1), 93.

3. Bostic, Raphael W. and Richard W. Martin (2005), Have Anti-Discrimination Housing Laws Worked? Evidence from Trends in Black Homeownership, Journal of Real Estate Finance and Economics, 31 (1), 5.

4. Brimmer, Andrew (1986), Black Income Mirrors Status in Economy, Black Enterprise, 17 (2), 33.

5. Chang, Regina Y. and Sherman Hanna (1992), Consumer Credit Search Behavior, Journal of Consumer Studies and Home Economics, 16, 207-27.

6. Dixon, Mary (1999), Partnerships to promote minority homeownership, America's Community Banker, 8 (3), 8.

7. Gabriel, Stuart and Gary Painter (2003), Pathways to Homeownership: An Analysis of the Residential Location and Homeownership Choices of Black Households in Los Angeles, Journal of Real Estate Finance and Economics, 27 (1), 87.

8. Leopold, Deborah (2006), Minority Access, Builder, 29 (12), 107. 
9. Mishra, Sanjay, U. N. Umesh, and Donald E. Stem, Jr. (1993), Antecedents of the attraction effect: An information-processing approach, JMR, Journal of Marketing Research, 30 (3), 331.

10. Murray, Michael (2002), An education for the mortgage industry, Mortgage Banking, 63 (2), 70.

11. Perry, Vanessa G. and Marlene D. Morris (2005), Who is in Control? The Role of Self-Perception, Knowledge, and Income in Explaining Consumer Financial Behavior, The Journal of Consumer Affairs, 39 (2), 299-313.

12. Woodruff, Robert B. (1997), Customer Value: The Next Source for Competitive Advantage, Journal of the Academy of Marketing Science, 25 (2), 139-53.

\section{NOTES}

